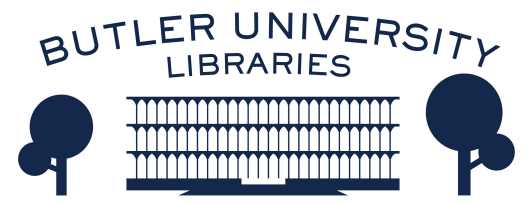

Booth

Volume 7 | Issue 9

Article 1

$9-4-2015$

\title{
Weather, Then You Picked the Wrong Place to Stay
}

Peter Twal

Follow this and additional works at: https://digitalcommons.butler.edu/booth

\section{Recommended Citation}

Twal, Peter (2015) "Weather, Then You Picked the Wrong Place to Stay," Booth: Vol. 7 : Iss. 9 , Article 1. Retrieved from: https://digitalcommons.butler.edu/booth/vol7/iss9/1

This Article is brought to you for free and open access by Digital Commons @ Butler University. It has been accepted for inclusion in Booth by an authorized editor of Digital Commons @ Butler University. For more information, please contact digitalscholarship@butler.edu. 


\title{
Weather, Then You Picked the Wrong Place to Stay
}

\author{
Abstract \\ And all memory is just like bagging the last pile of leaves in the fall and the dew soaking through my \\ shoes and the water moccasin nestled at the heart of it all \\ Cover Page Footnote \\ Weather, Then You Picked the Wrong Place to Stay was originally published at Booth.
}




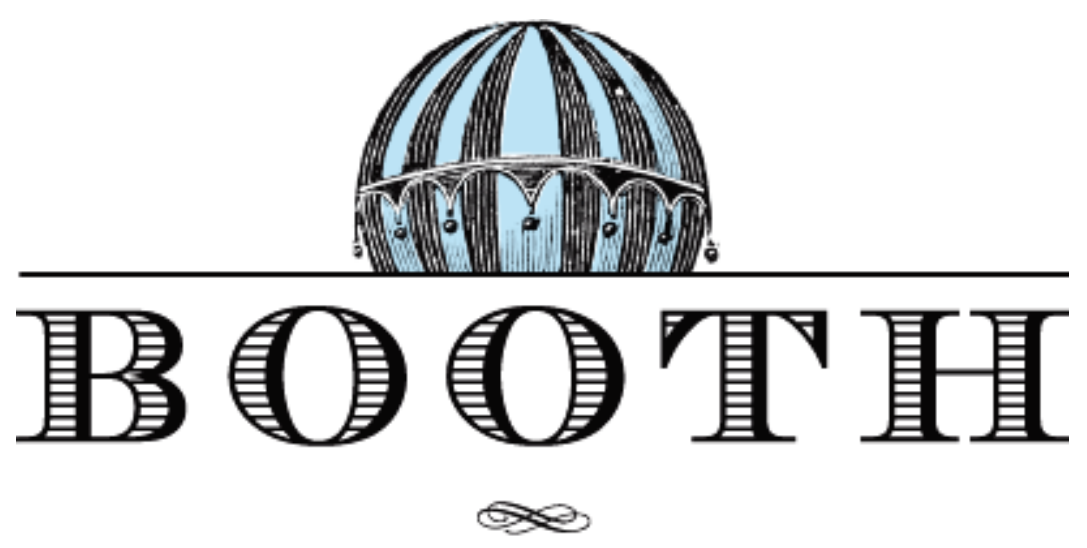

A JOURNAL

September 4, 2015

\title{
Weather, Then You Picked the Wrong Place to Stay
}

\author{
by Peter Twal
}

And all memory is just like bagging the last pile of leaves in the fall and the dew soaking through my shoes and the water moccasin nestled at the heart of it all Could it be that simple your ghost more afraid of me than I should be of it every time I say your name in the mirror or tape together some lightning rods in your likeness and why, here we are my living room you wrapping a plastic bag around my head and my tongue trying to poke a hole through the past Should I mention I like what you've done with your hair Taking this chance to impress you, scrawling mental notes across my palm like don't look away at dinner when her jaws ratcheting closed like a cartoon bear trap tear apart her lamb meat or your arm Note: mirrors help to heal phantom limbs All memory is just the desire to kill someone or thing again Same as baby teeth, our earliest tattoos eventually fall out, you told me that the teetering bookshelf tattooed down my back will crumble, leaving my spine in such masterpieces You're in the room but a text: we've already conceived of the atomic bomb, yes, so fuck the table setting tonight Another: should I melt the butter or sharpen the butter knife instead One more: fork goes on the inside or outside of the body

\footnotetext{
Peter Twal is an Arab American, an electrical engineer, and an editor at PARAGRAPHITI. Recently graduated with an MFA from the University of Notre Dame, he is the recipient of the Samuel and Mary Anne Hazo Poetry Award, and his poetry has appeared or is forthcoming in Kenyon Review Online, The Journal, Yemassee, DIAGRAM, Bat City Review, New Delta Review, Forklift, Ohio, New Orleans Review, and elsewhere.
} 